\title{
Plasma Processing of Municipal Solid Waste
}

\author{
Edbertho Leal-Quirós \\ Scientific Research Department \\ Polytechnic University of Puerto Rico \\ PO Box 192017, San Juan, PR 00919-2017
}

Received on 03 February, 2004; revised version received on 04 June, 2004

\begin{abstract}
In this paper a review and assessment of the Hot Temperature Plasma Processing of Waste is presented. The environmental advantage of this method over incineration is clearly demonstrated. The present technology of Plasma Arcs and the Modern Plasma Torches Applications are also shown. An Assessment of the Heavy Duty Gasification Combined Cycle Turbines, Gasification Process, Magmavication/Vitrification process, and Environmental Engineering Protection are also described.
\end{abstract}

\section{Introduction}

Imagine a process in which we convert the inorganic components of the municipal solid waste in architectural tiles and construction bricks, at the same time we convert all the organic contents of the waste into Synthesis gas, (basically a mix of $\mathrm{H}_{2}+\mathrm{CO}$, almost a green fuel) and in addition we generate electrical power. Furthermore, could we have a system that doesn't generate ashes, and doesn't pollute the air, the water nor the soil, as incineration does? The answer is yes. The plasma torches that operate at very high temperatures (between $5,000^{\circ} \mathrm{C}$ and $100,000^{\circ} \mathrm{C}$ ) can process all kinds of waste: municipal solid, toxic, medical, biohazard, industrial and nuclear waste at atmospheric pressure. Effectively, the inorganic waste is vitrified in solid-like glass materials that are used to manufacture aggregates for the construction industry (Magmavication process) and the organic materials (plastics, paper, oil, bio-materials, etc.) are converted into Syngas with caloric value, fuel that is used on the Heavyduty advanced gas turbines for the generation of electrical power (Gasification process). No ashes are produced because at more than $5,000^{\circ} \mathrm{C}$, all the organic molecules are disintegrated and only the mix of $\mathrm{H}_{2}+\mathrm{CO}$ remains at high temperature.

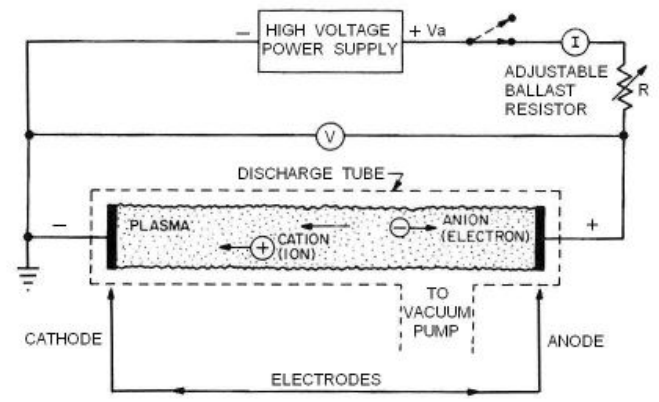

Figure 1. Chemical properties and components of average municipal solid waste.

\section{Plasma and it's technological evolu- tion: from discharge tubes to tor- ches}

Plasma is the ionized state of matter, it's conformed by a quasi-neutral gas composed of charged and neutral particles, which exhibit a collective behavior; plasma is the most abundant form of matter in the universe. It is formed whenever ordinary matter is heated over $5,000{ }^{\circ} \mathrm{C}$, which results in electrically charged gases or fluids. They are profoundly influenced by the electrical interactions of the ions and electrons by the presence of a magnetic field.

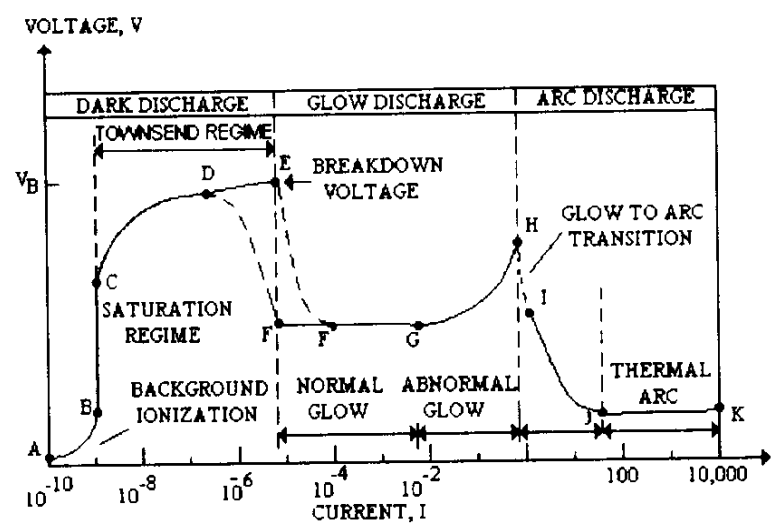

Figure 2. Universal voltage-current curve characteristic of the DC low-pressure electrical discharge tube.

Plasma produced with DC electrical discharge has been the precursor of a modern and more efficient Plasma Torch device $^{1}$. Taken an electrical discharge tube $[2,3,4]$-like the classical schematic shown in the Fig. 1 and raising the voltage $\mathbf{V}$, while measuring the current $\mathbf{I}$ following through

\footnotetext{
${ }^{1}$ Reed J. Roth [3] gives a comprehensive review of the evolution of the plasma technology to the modern Transferred and Non-Transferred Plasma torch and it is used for this review.
} 
the discharge, the result is a high nonlinear Voltage-Current curve. The three major regimes of industrially important DC low-pressure electrical discharges tubes are:the Dark Discharge, the Glow Discharge and the Arc Discharge (Shown in Fig. 2).

The arc regime is comprised of three regions: the glow to arc transition, the non-thermal arcs, and the thermal arcs. When the current density is great enough to heat the cathode to incandescence, then a discontinuous glow-to-arc transition region appears in the Voltage-Current characteristic curve. This glow-to-arc transition happens for currents between 1 and 10 Amperes at low pressures.

As we can see in Fig. 3, thermal arcs always are found at higher pressures and higher gas temperature than nonthermal arcs; however, non-thermal arcs may also exist at atmospheric pressure.

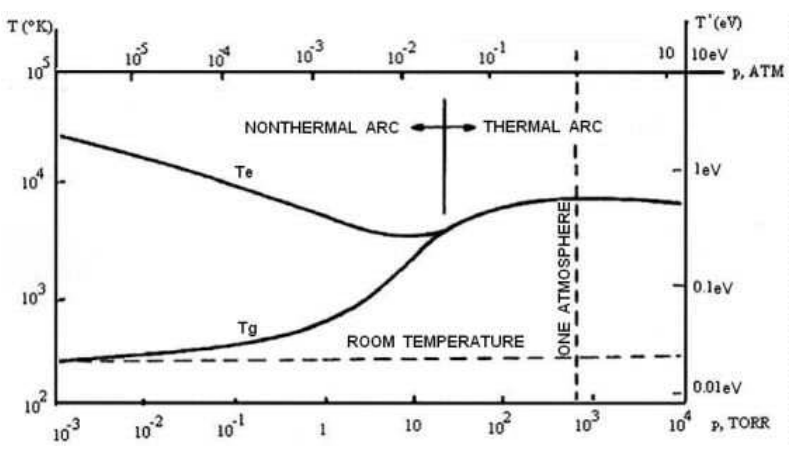

Figure 3. The operation of area as a function of pressure.

The total current of arcs is always more than 1 ampere and the current density ranges from several amperes per square centimeter to more than thousand amperes per square centimeter. The electron density of thermal arcs is higher than in non-thermal arcs.

In non-thermal arcs, low emission arcs usually require thermionic emission from cathodes, whereas in thermal arcs, high intensity arcs usually operate in field emissions.

Thermal arcs can be considered in thermodynamic equilibrium. Figs. 4, 5 and 6 show different types of arcs and torches: the transpiration stabilized arc, the coaxial flow stabilized arc and the axe symmetric, non-transferred, unmagnetized arc jet or plasma torch.

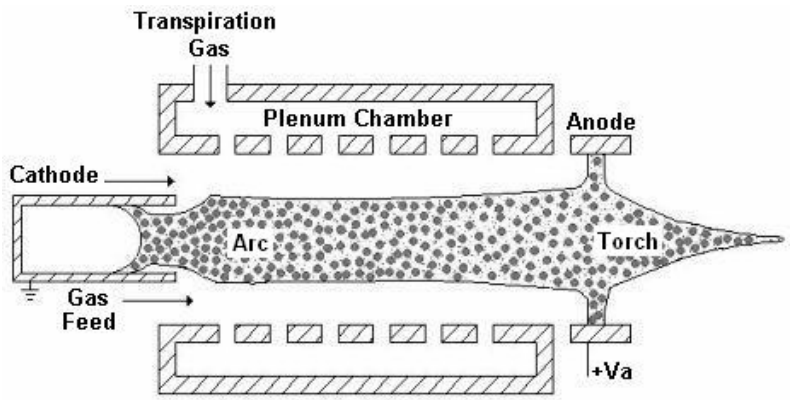

Figure 4. The transpiration stabilized arc, with the arc column maintained in a centered position by radial, inward injection of cooling water or gas.

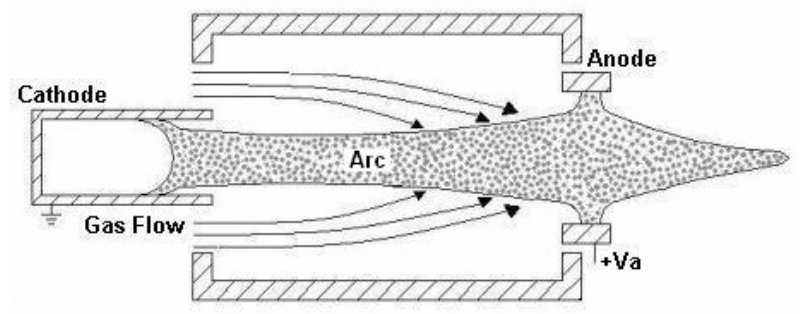

Figure 5. The coaxial flow stabilized arc with laminar flow of stabilizing gas.

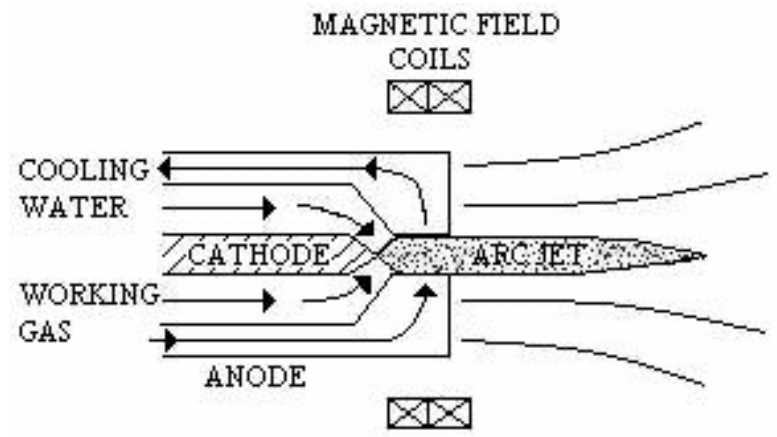

Figure 6. The axe symmetric, non-transferred, unmagnetized arc jet or plasma torch. An are is struck between the cathode and the coaxial anode, and working gas is heated by passage through the arc region.

\section{Cascade process of ionization}

In a cascade process, one incident electron $\left(\mathrm{e}^{-}\right)$collides with a neutral atom ( (../.././Plasma/Documentsisn't in document $)$ to produce a second electron and an ion ( (../.././Plasma/Documentsisn't in document ). There are then two electrons and one ion. After these two electrons have each collided with another neutral atom, there are produced four electrons and three ions. This process continues and, after about 20 successive sets of collisions, millions of electrons and ions will have been formed rapidly (the mean free path between collisions is very small at atmospheric pressures).

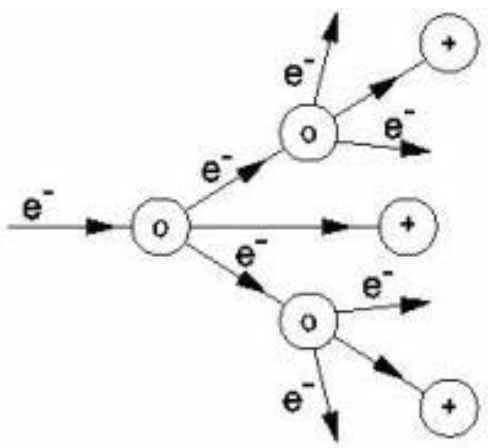

Figure 7. Cascade process of ionization 
The Debye length is a measure of the width of the effective electric field of an ion and is given approximately by the next formula, in which $\mathbf{T}_{e}$ is the electron temperature and $\mathbf{n}_{e}$ is the number density of electrons (per mL). $\lambda_{D}=$ 6.9 $\left(\mathbf{T}_{e} / \mathbf{n}_{e}\right)^{1 / 2}$. For a plasma temperature of $\mathbf{8 , 0 0 0}{ }^{\circ} \mathbf{K}$ and $\mathbf{n}_{e}=\mathbf{1 0}^{14} / \mathbf{c m}^{3}, \lambda_{D}$ is about $0.0006 \mathrm{~mm}$, which is very much smaller than the $1 \mathrm{~mm}$ sampler orifice and so ions can pass through easily. Hot gases from the plasma impinge on the edges of the sampler orifice so that deposits build up and reduce its diameter with time. The surroundings of the sampler orifice suffer also from corrosive effects due to bombardment by hot species from the plasma flame. These problems necessitate replacement of the sampler from time to time. As the gas leaves the other side of the sampler orifice, it experiences a vacuum of about $10^{-5}$ Torr and the expanding jet of gas cools very rapidly and reaches supersonic speeds.

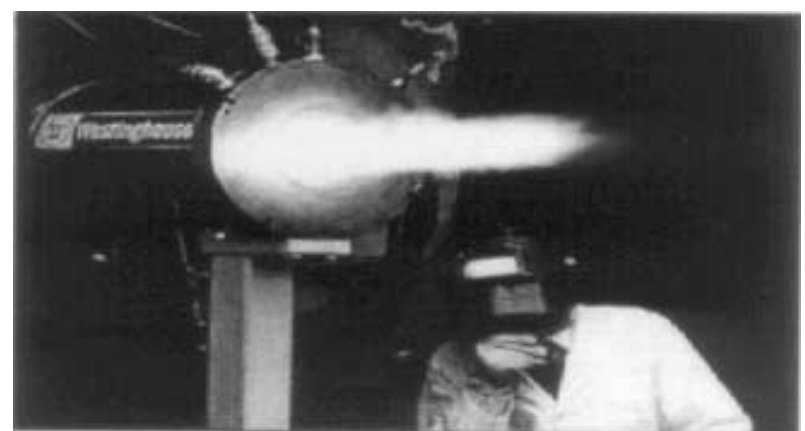

Figure 8. Photograph of a high power plasma torch, manufactured by Westinghouse [10].

\section{Modern high power plasma torches}

Westinghouse in his Plasma Center ${ }^{2}$, has produced modern High Power Plasma Torches [4,5]. The author visited that facility, inspected one torch, and noticed the excellent performance. There are several manufacturers of plasma torches (a list of them is available on the web). However, to the author knowledge, only Westinghouse manufactures torches of high power even in the order of $10 \mathrm{MW}$ (Fig. 8). Models similar to this torch are commercially available even in the range of $75 \mathrm{KW}$ to $10,000 \mathrm{~kW}$ of power. A thermal efficiency of $90 \%$ is easily possible; the efficiency represents the percentage of arc power that exits the torch and enters the process. However, the operational characteristics of each torch depend of the gas composition. The most common gases used in plasma torches are Argon, and Helium. The quality of the plasma produced depends on the plasma density and the plasma temperature; at atmospheric pressure plasma torches may produce a density of $10^{14} \mathrm{~cm}^{-3}$. As more power is given to the torch, there is better quality of plasma. Due to the broad range of plasma temperatures and densities, plasmas have several applications in research, technology and in the industry.

\section{Plasma magmavication or vitrifica- tion process}

Plasma torches provide efficient means for melting solids or waste materials into magma or a lava form, after a short time of interaction of the plasma $\left(\mathrm{T}>5000^{\circ} \mathrm{C}\right)$ with the solids. In a longer cooling time, the resulting mass forms a chemically and physically durable igneous rock. Depending upon the original mineralogy and rate of cooling, the final product consists of either amorphous glassy material resembling volcanic obsidian or a crystalline igneous rock similar to granite or basalt. Several applications have been done in the construction industry (Circeo [6,7,8] et al., 2000 at Georgia Tech). The Georgia Tech group found a formula for the amount of vitrified mass produced, as a function of the plasma torches energies. The mass produced obeys the relation: $\mathbf{M}(\mathrm{kg})=0.35 \mathrm{P}(\mathrm{kW}-\mathrm{hr})$, where $\mathbf{M}$ is the vitrified mass-produced in $\mathrm{Kg}$, and $\mathbf{P}$ is the electrical energy consumed in the process. One application is for remediation of radioactive waste, where highly radioactive liquid and sludge are mixed with glass particles and heated to very high temperatures to produce a molten glass. This molten glass is then poured into stainless steel canisters. When the mixture cools, it hardens into a stable glass that traps the radioactive elements and prevents them from moving through the air or water into the environment. DOE is currently operating vitrification plants at the Savannah River Site in South Carolina and the West Valley Demonstration Project in New York. In Japan, Kobe $[9,13,14]$ Steel LTD and The Kansai Electric Power Company developed a Plasma vitrification system.

\section{High temperature plasma proces- sing of waste}

Solid waste from municipalities can be processed using high-energy plasma torches. Plasma can process any kind of waste. The chemical properties and the contents of the average municipal waste are shown in Table 1.

Westinghouse [12] has conducted many successful experiments, designs and developments involving the gasification and/or Vitrification of simulated MSW (municipal solid waste), ASR (auto shredder residue), fossil fuels, and industrial liquid and solid wastes in a plasma reactor.

The gasification test material feed ranged from low Btu MSW (1600 kcal/kg) to medium Btu simulated auto shredder residue $(4500 \mathrm{kcal} / \mathrm{kg})$ and to high Btu coal $(8,000$ $\mathrm{kcal} / \mathrm{kg}$ ).

Experiments were conducted where fuels were gasified to produce primarily carbon monoxide, $\mathrm{CO}$ and hydrogen, $\mathrm{H}_{2}$. The inorganic components of the feed were converted to molten slag that was removed as vitrified by product. The slag passed the EPA-mandated Toxicity Characteristic Leachate Procedure (TCLP) requirements. Emissions are very much reduced and the slag is a glassy product with value as a construction material base. Dioxins were measured at levels approximately 100 times lower than from an

${ }^{2}$ Waltz Mill Site, Madison Pennsylvania Plant. 
TABLE 1. Chemical properties and components of average municipal solid waste.

\begin{tabular}{|c|c|c|c|c|c|c|c|c|c|c|c|c|}
\hline $\begin{array}{l}\text { Chem. } \\
\text { Comp. } \\
{[\mathrm{mg} / \mathrm{kg}]}\end{array}$ & $\begin{array}{l}\text { Melting } \\
\text { Point } \\
{ }^{\circ} \mathrm{C} \\
{[1 \text { atm }]}\end{array}$ & $\begin{array}{l}\text { Normal } \\
\text { Boiling } \\
\text { Point } \\
{ }^{o} \mathrm{C}\end{array}$ & $\begin{array}{l}\text { Ionization } \\
\text { Potential } \\
{[\mathrm{eV}]}\end{array}$ & $\begin{array}{l}\text { Dry solid } \\
\text { Waste } \\
{[31.63 \%]}\end{array}$ & $\begin{array}{l}\text { Food } \\
\text { Waste } \\
{[36.61 \%]}\end{array}$ & $\begin{array}{l}\text { Sludge } \\
\text { Oil } \\
{[11.65 \%]}\end{array}$ & $\begin{array}{l}\text { Grey \& } \\
\text { Black } \\
\text { Water } \\
\text { Sludge } \\
{[19.82 \%]}\end{array}$ & $\begin{array}{l}\text { Grey \& } \\
\text { Black } \\
\text { Water } \\
\text { pre- } \\
\text { filtration }\end{array}$ & $\begin{array}{l}\text { Oily } \\
\text { Filters } \\
{[0.02 \%]}\end{array}$ & $\begin{array}{l}\text { Oily } \\
\text { Rags } \\
{[0.10 \%]}\end{array}$ & $\begin{array}{l}\text { Medical } \\
\text { waste } \\
{[0.02 \%]}\end{array}$ & $\begin{array}{l}\sum \text { total } \\
{[\mathrm{mg} / \mathrm{kg}]}\end{array}$ \\
\hline$\overline{\mathrm{C}}$ & $4,492.00$ & $3,642.00$ & 11.260 & $90,440.07$ & $24,597.89$ & $68,789.64$ & $11,303.82$ & 757.28 & 132.16 & 460.64 & 58.20 & $196,548.69$ \\
\hline$\overline{\mathrm{H}}$ & -259.34 & -252.97 & 13,598 & $11,959.64$ & $3,513.98$ & $9,184.76$ & $1,909.61$ & 127.93 & 20.69 & 62.36 & 8.31 & $26,787.29()$ \\
\hline $\mathrm{O}$ & -218.79 & -182.95 & 13,618 & $56,326.60$ & $17,643.13$ & 820.22 & $4,178.20$ & 279.91 & 0.32 & 218.88 & 58.20 & $79,525.46$ \\
\hline $\bar{N}$ & -210.00 & -195.79 & 14,434 & 382.63 & $1,537.37$ & 246.07 & 981.80 & 65.77 & 0.10 & 25.48 & 0.26 & $3,239.47$ \\
\hline $\mathrm{S}$ & 115.21 & 444.60 & 10,360 & 343.55 & 73.21 & $2,895.74$ & 23.18 & 1.55 & 1.60 & 12.16 & 0.40 & $3,351.38$ \\
\hline $\mathrm{Cd}$ & 321.07 & 767.00 & 8,993 & 0.23 & & & 0.39 & 0.03 & 0.0058 & 0.00025 & 0.00003 & 0.6436 \\
\hline $\mathrm{Cr}$ & $1,907.00$ & $2,671.00$ & 6,766 & 6.04 & & & 0.79 & 0.05 & 0.0051 & 0.02888 & 0.0345 & 6.9193 \\
\hline $\mathrm{Cu}$ & $1,084.62$ & $2,562.00$ & 7,726 & 12.75 & & & 50.88 & 3.41 & .0073 & 0.0156 & 0.17 & 67.2243 \\
\hline $\mathrm{Ni}$ & $1,455.00$ & $2,913.00$ & 7,639 & 2.25 & & & 1.96 & 0.13 & 0.0018 & 0.00860 & 0.00157 & 4.3536 \\
\hline $\mathrm{Pb}$ & 327.46 & $1,749.00$ & 7,416 & 26.01 & & & 1.99 & 0.13 & 0.0159 & 0.06 & 0.00345 & 28.2185 \\
\hline $\mathrm{Zn}$ & 419.53 & 907.00 & 9,394 & 30.79 & & & 59.09 & 3.96 & 0.0177 & 0.0376 & 0.08753 & 93.9698 \\
\hline Sn & 231.93 & $2,519.00$ & 7,343 & 1.03 & & & 0.09 & .0061 & 0.0028 & & & 1.1246 \\
\hline $\mathrm{Cl}$ & -101.50 & -34.04 & 12.967 & $1,034.93$ & 549.06 & & 172.42 & 11.55 & 2.96 & 2.24 & 1.80 & $1,774.97$ \\
\hline $\mathrm{F}$ & -219.62 & -188.12 & 17.422 & 21.19 & & & 0.05 & 0.0035 & 0.016 & & & 21.2468 \\
\hline $\mathrm{Al}$ & 660.32 & $2,519.00$ & 5.985 & $2,860.54$ & & 4.07 & & & 0.0010 & 0.0060 & 0.23 & $2,864.85$ \\
\hline $\mathrm{Fe}$ & $1,538.00$ & $2,861.00$ & 7.902 & $11,473.79$ & & & & & & & & $11,473.79$ \\
\hline $\mathrm{Hg}$ & -38.83 & 356.73 & 10.437 & & & & 0.02 & 0.0011 & & & 0.00001 & 0.0179 \\
\hline As & 817.00 & 614.00 & 9.815 & & & & 0.42 & 0.03 & & & 0.0028 & 0.4451 \\
\hline $\mathrm{Sb}$ & 630.63 & $1,587.00$ & 8.640 & & & & & & & & 0.00056 & 0.00056 \\
\hline $\mathrm{Tl}$ & 304.00 & $1,473.00$ & 6.108 & & & & 7.95 & 0.53 & & & 0.00028 & 8.4870 \\
\hline $\mathrm{Ag}$ & 961.78 & $2,162.00$ & 7.576 & & & & 2.83 & 0.19 & & & & 3.0185 \\
\hline $\mathrm{Br}$ & -7.20 & 58.80 & 11.813 & & & & 1.05 & 0.07 & & & & 1.1253 \\
\hline$\overline{\mathrm{Ba}}$ & 727.00 & $1,897.00$ & 5.211 & & & & 3.95 & 0.26 & & & & 4.2113 \\
\hline $\mathrm{Se}$ & 221.00 & 685.00 & 9.752 & & & & 3.79 & 0.25 & & & & 4.0474 \\
\hline $\mathrm{Si}$ & $1,414.00$ & $3,265.00$ & 8.151 & & & 4.07 & & & 0.0010 & 0.0060 & & 4.0747 \\
\hline $\bar{V}$ & $1,910.00$ & & 6.746 & & & 49.41 & & & 0.0230 & 0.1440 & & 49.5798 \\
\hline $\begin{array}{l}\mathrm{Na}_{2} \mathrm{CO}_{3} \\
\mathrm{CaCO} 3 \\
\mathrm{SiO} 3 \\
\text { (Glass) }\end{array}$ & 858.10 & & & $96,805.03$ & & & & & & & & $96,805.03$ \\
\hline $\mathrm{H} 2 \mathrm{O}$ & 0.00 & 100.00 & 12.612 & $32,644.59$ & $311,134.00$ & $22,975.58$ & $181,253.89$ & 332.00 & 1.60 & 202.00 & 32.00 & $548,575.67$ \\
\hline Ash/Inert & & & & $11,919.84$ & $6,991.36$ & $11,481.46$ & $1,118.72$ & 74.95 & 0.49 & 15.93 & 0.33 & $31,603.09$ \\
\hline
\end{tabular}

incineration plant (e.g., $<0.01 \mathrm{ng} / \mathrm{nm}^{3}$ measured in stack gas), and predicted fuel gas production is observed. For organic waste, the production of power via a combustion/turbine combined cycle at much higher efficiencies (approximately $40 \%$ thermal efficiency versus approximately $20 \%$ for an incineration steam boiler plant) is an added benefit which makes the project cost attractive compared to incinerator/steam boiler MSW plants. Additionally, the high quality glassy material produced can be sold as a roadbed or construction material and the need and expense to dispose of ash is eliminated.

\section{Metal-electrode-plasma applications}

The plasma energy corporation has investigated the use of this plasma technology for treatment of municipal waste, used tires, polychlorobenzyl (PCB), oils and medical wastes (Pocklington and Corox [3], 1992; Camacho [5], 1990) since plasma can provide thermal decomposition of some toxic molecules into simple benign one's. A $300-\mathrm{kW}$ level power operation has been used in a range of experiments. Hydrocarbon waste is fed into the furnace through a double door air lock system. A molten pool was formed in the earth. In some experiments, steam was injected to generate hydrogen-rich gas that could be used in future applications for energy production. The gases produced by the furnace were scrubbed to control chlorine and sulfur emissions. The inorganic and metals in the molten pool of the furnace were tapped, and vitrified (glass-like) slag and metal product was obtained. The electrical power requirement for conversion of one ton of municipal solid waste into the final products of vitrified solids and metals, hydrogen and carbon monoxide gas was $550-790 \mathrm{~kW} \mathrm{~h}$. Typically $20 \%$ of the initial waste is converted into solid products. The remainder is converted into gas. Combustion of the hydrogen and carbon monoxide in the gas could be used to offset the electrical power requirement.

\section{Plasma gasification processes of waste}

Gasification $[9,11,13]$ is a simple and commercially wellproven technology. It involves the conversion of various feedstocks to clean syngas, through a reaction with oxygen and steam; this reaction is spontaneous at high temperature and pressure under reduction conditions, and consumes half of the oxygen required for total combustion. The raw syngas product is cooled and purified, it is then used in one or a combination of many product applications: syngas for chemicals, gaseous fuels, for liquid fuels burned in commercial boilers to produce steam or in heat transfer process and in internal combustion engines to produce electrical energy. Combined cycles are also possible leading to co-generation 


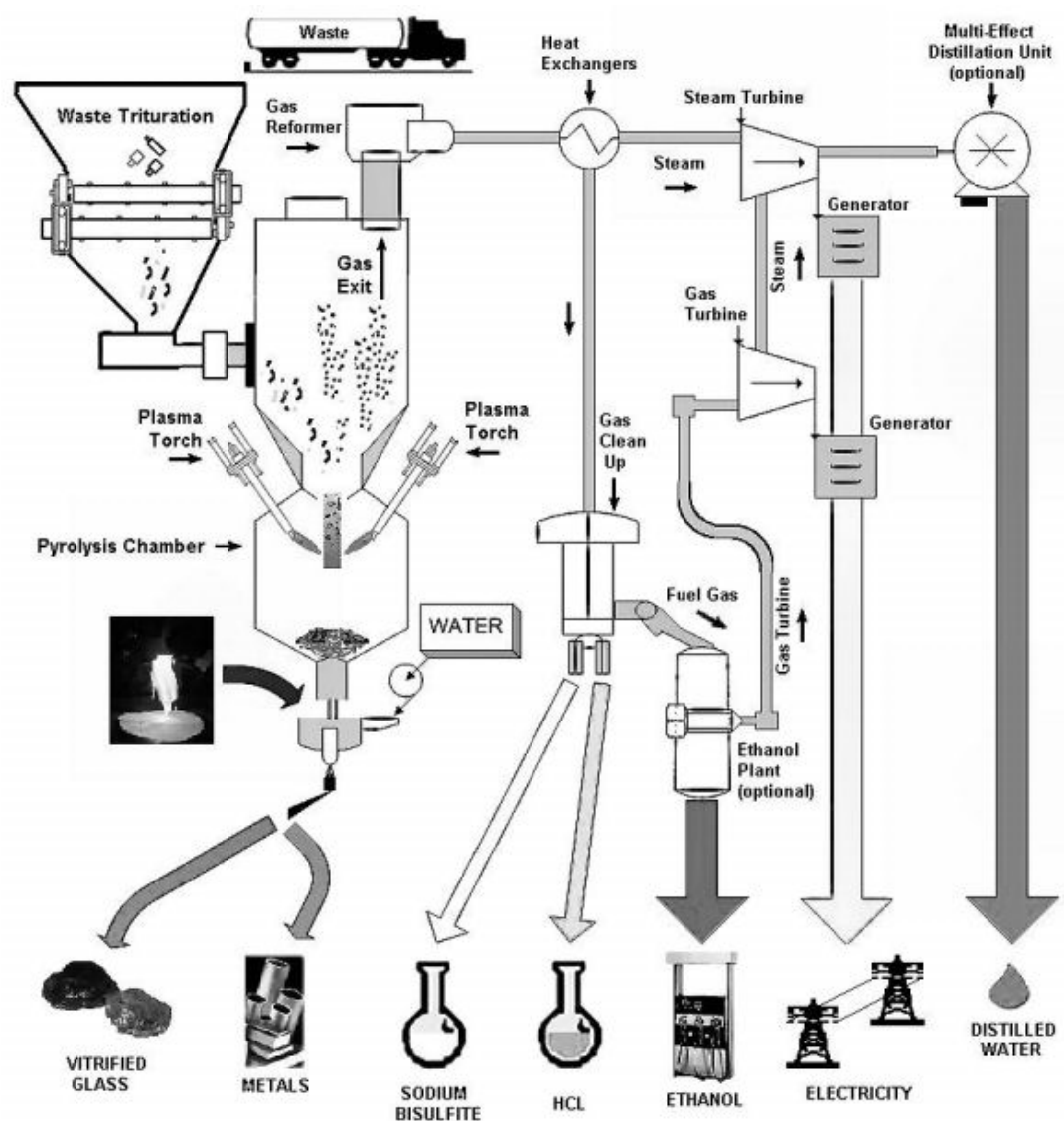

Figure 9. Artistic drawing of the plasma waste processing plant.

of electrical energy. The energy efficiency of biomass gasification varies from 75 to $80 \%$, this depends of the composition and heat capacity of the raw material; Humidity and the inorganic inert matter content reduce the efficiency. The traditional market for syngas is focused in gas production as an intermediate step during the production of important chemicals, such as ammonia for fertilizer. However, application of gasification in other processes is increasing due to market changes associated with improved gas turbines, deregulation of electrical power generation, and stringent environmental mandates. Gasification plant capacity is reported in units of volumetric output of syngas (i.e., normal cubic meters per day). However, the Department of Energy (DOE) converted all the gasification input and output capacities to $\mathrm{MW}_{t h}$. $\left(1 \mathrm{MW}_{t h}=3,413,000 \mathrm{Btu} / \mathrm{hr}\right)$. Gasification is an alternative to combustion, and has an energy efficiency of $50 \%$. The advantage consists on reducing both the atmospheric emissions and the volume of solid residues to be land filled. Since the solid residues come from a high temperature at normal conditions, they're inert materials that can be used as part of the bulk material in concrete production.

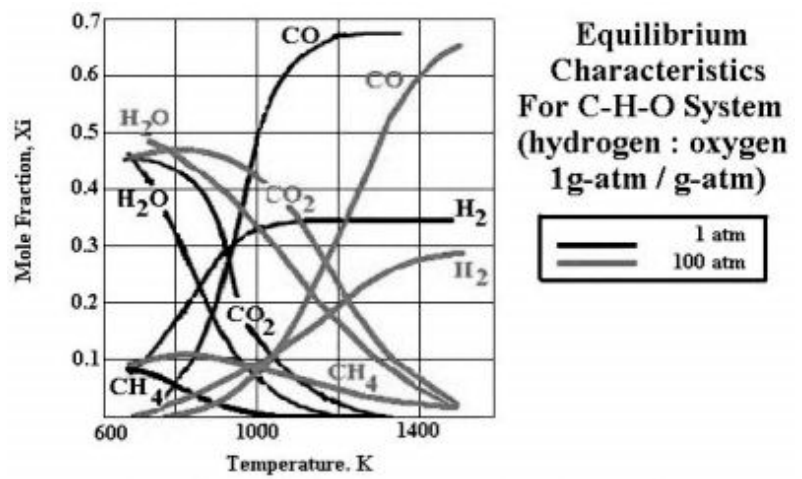

Figure 10. From all the organic components of waste, only the molecules of $\mathrm{CO}$ and $\mathrm{H} 2$ (syngas) resist the high temperature of the plasma torch.

\section{Synthesis gas cleaning island}

The purpose of this system is to remove pollutants such as sulfur dioxide (SO2), particulate matter, hydrochloric acid $(\mathrm{HCl})$ and Hydrogen Sulfide $\left(\mathrm{H}_{2} \mathrm{~S}\right)$ vapors from the synthesis gas. The primary design requirements are environmental protection and safe operation of the gas turbine. The basic unit operations are those of gas cooling, particulate removal, and acid gas neutralization. First, the syngas is sufficiently cooled prior to gas cleanup it is passed through a partial 
quench. The gas leaves the chamber at $350{ }^{\circ} \mathrm{C}$. The goal is to lower the gas temperature sufficiently so as not to damage the downstream equipment while maintaining the gas above saturation temperature. The gas then passes through a fabric filter bag-house to remove particulates. The blowers are each sized at $100 \%$ to provide full redundancy. The gas is then in a saturation tank, which lowers the gas temperature to $50{ }^{\circ} \mathrm{C}$, then it passes through a packed bed aqueous scrubber for acid remove. Sodium hydroxide solution is used to neutralize the acid. The gas, still "sour" at this point, then undergoes first stage compression for use in the gas turbine. It then enters the lower section of the $\mathrm{H}_{2} \mathrm{~S}$ Absorber Vessel and flows countercurrent to a regenerated solution of chelated iron oxide $\left(\mathrm{FeO}_{2}\right)$ fluid for removal of any $\mathrm{H}_{2} \mathrm{~S}$. The $\mathrm{H}_{2} \mathrm{~S}$ absorbed by the solution is removed from the bottom of the $\mathrm{H}_{2} \mathrm{~S}$ Absorber Vessel and circulated by the Rich Solution Pump, through a Solution Cooler, and into the Solution Oxidizer Tank, where Air Blower introduces air. The air blower agitation causes the elemental sulfur to precipitate, forming slurry at the bottom of the Solution Oxidizer Tank. The slurry is removed from Solution Oxidizer Tank by a Sulfur Slurry Pump Tag and sent to a conveyor Sulfur Filter. The filtrate solution drains off and is returned to the Solution Oxidizer Tank, while the wet inert sulfur cake is collected for disposal to a non-hazardous landfill. At this point, the gas exiting the $\mathrm{H}_{2} \mathrm{~S}$ Absorber Vessel is considered 'clean' for use as a fuel gas. Specific Heat Capacity of Syngas $=1.488 \mathrm{~kJ} / \mathrm{kg} . \mathrm{K}$

\section{Gas turbine excess of energy and green energy}

The Lower Heating Value (LHV) of the natural gas supply is assumed to be $11,900 \mathrm{kcal} / \mathrm{kg}$. The minimum LHV acceptable to the CTG is assumed to be $3,600 \mathrm{kcal} . \mathrm{kg}$. The ability of the Integrated Plasma Gasification Combined Cycle System (IPGCC) to use low calorific value (LCV) feedstock, and produce high value co-products, along with energy, enhance the economic viability of new projects. The ability to successfully burn LCV fuels like the case of municipal solid waste required that GE modified the can-annular combustion systems since 1990. GE concluded that a Syngas fueled combined cycle plant can have the same ReliabilityAvailability-Maintenance (RAM) performance as a natural gas-fueled combined cycle plant. IPGCC shows superior environmental performance and viability, also the power plant emissions are far below any other coal technology, for all the major pollutant categories $\left(\mathrm{NO}_{x}, \mathrm{SO}_{x}\right.$, metals, mercury, $\mathrm{CO}_{2}$, sludge, water).

\section{IPGCC environmental perfor- mance}

IPGCC is inherently "greener" than any other coal technology. In the process, harmful pollutants can be removed from the syngas before they reach the gas turbine; thus, back-end exhaust gas clean up is not necessary. The $\mathrm{SO}_{x}$,
$\mathrm{NO}_{x}$, mercury, metals, and particle emissions from the plant are fractions of those of a conventional pulverized coal boiler power plant. Consequently, IPGCC plants require significantly less effort and time to meet air emissions regulations and to obtain local and state governmental environmental permits. The process is approximately $5 \%$ more efficient than other coal power technologies; thus, $\mathrm{CO}_{2}$ emissions per $\mathrm{kW}$ are also $5 \%$ lower. Additionally, in the process, carbon can be removed from the syngas to create a high hydrogen fuel that effectively eliminates $\mathrm{CO}_{2}$ emissions. The advantage of IPGCC over conventional boiler plants for $\mathrm{CO}_{2}$ reduction is that the carbon can be removed from the fuel gas (pre-combustion) instead of having to remove it from the exhaust (flue) gas (post-combustion), which is far more costly because of the larger SCR volume required (about 10: $1)$.

\section{Conclusion and general assess- ment}

The Plasma Torches technology is mature, reliable and a well-known method of producing plasma at atmospheric pressure and temperatures larger than $5,000{ }^{\circ} \mathrm{C}$; this may disintegrate all mater, in particular solid waste, creating $g a$ sification because the organic materials are converted in syngas, which is cleaned before being used in the Turbine. Magmavication or Vitrification is the result of the interaction between plasma and inorganic materials, in presence of a coke bed in the cupola or reactor, a vitrified material is produced and products are used in the manufacture of architectural tiles and construction materials.

Integrated Plasma Gasification Combined Cycle System (IPGCC) generates green electrical power using heavy duty Turbines; the heat from the non-transferred electric plasma torch is used to gasify the waste, producing a synthetic fuel gas that is then cleaned. The cleaned syngas will then be combusted in two simple cycle combustion turbines to produce electricity for internal consumption, as well as for export to the electric grid. The reactor will be designed to handle some liquid waste mixed with the solids. The plant is designed for continuous operation, twenty-four hours a day, seven days a week and about 330 days per year. Although at first look the IPGCC process appears new, it is in fact a repackaging of existing, proven technologies.

To the author knowledge, the IPGCC plasma process MSW is the only environmentally ideal technology that we have today to process waste.

\section{References}

[1] E. Leal-Quirós, Advanced Analyzers and Probes for FusionPlasma Diagnostics, Current Trends in International Fusion Research. Second Symposium Edit by E. Panarella (NRC Research Press, National Research Council of Canada, Ottawa, ONK1A 0R6) 1999. 
[2] D. R. Cohn, Plasma Science and the Environment. Chap 9, Manheimer W., Sugiyama L. E., Stix T. H., (editors) (AIP Press-American Institute of Physics, Woodbury, New York) 1996.

[3] J. R. Roth, Industrial Plasma Engineering, Volume 2. Applications to Non-thermal Plasma Processing, (IOP Institute of Physics Publishing, Bristol) 2001.

[4] S. L. Camacho, Plasma Pyrolysis of Medical Waste in Proceedings of the First International EPRI Plasma Symposium, EPRI Center for Materials Production, Report No. CM90-9, May (1990).

[5] S. L. Camacho, "The plasma arc torch: its electrical and thermal characteristics" Proc. Int. Symp. On Envir. Technol. by Plasma system \& Applications, Vol. I, Georgia Tech Research Corporation, Atlanta. P 45-66 (1995).

[6] B. P. Spalding, and G. K. Jacobs, Evaluation of an In-situ vitrification Field demostration of a simulated radioactive liquid waste disposal trench, Pub. No. 3332, ORNL/TM10992, Oak Ridge National Laboratory, Oak Ridge, Tenn. (1989).

[7] J. Louis Circeo, Private communication.

[8] J. E. Surma, D. R. Cohn, et al. Proc. of information exchange meeting on Waste Retrieval, Treatment and Processing, U.S. Dept. of Energy Environmental Exchange Restora- tion and Waste Management Technology Development Program, Houston, Texas, March, p 391. (1993).

[9] R. T. Do and G. Letherman, 2001, Renewable Energy Market: Waste to Energy utilizing Plasma Technology, (Global Plasma Systems Corporation), Solena Presentation to the annual meeting of the Society of Women Engineers at PUPR, Polytechnic University of Puerto Rico, Hato Rey, P. R., April 23, 2001.

[10] www.westinghouse-plasma.com, www.sfapacific.com, www.fe.doe.gov, www.gasification.org, www.netl.doe.gov

[11] A. D. Foster, H. E. von Doering, and M. B. Hilt, "Fuels Flexibility in Heavy-Duty Gas Turbines," GE Company, Schenectady, New York, 1983.

[12] Shyam V. Dighe, et al: 2001, Private communication.

[13] S. Lavoie and J. Lachance, "Five years of Industrial Experience with the Plasma Dross Treatment Process". Proc. Third International Symposium Recycling of Metals and Engineering Materials. Edit by Queneau, P., and Peterson, R. (A publication of TMS) 1995.

[14] Mitsubishi heavy industries, LTD.5-1, Marunouchi 2-chome, Chiyoda-ku, Tokyo 100 TEL03-3212-3111, FAX03-3212984. 